\title{
The Electrical and Optical Properties of $\mathrm{Zn}_{0.5} \mathrm{Li}_{2 \mathrm{x}} \mathrm{Mg}_{0.5-\mathrm{x}} \mathrm{Fe}_{2} \mathrm{O}_{4}$ Lithium Doped Nanoparticle Prepared by Coprecipitation Method
}

\author{
Nisreen A. Elthair ${ }^{1,2}$, Eltayeb M. Mustafa1, Abdelrahman A. Elbadawi ${ }^{1,3}$ \\ ${ }^{1}$ Department of Physics, Faculty of Science and Technology, Al Neelain University, Khartoum, Sudan \\ ${ }^{2}$ Department of Physics, Faculty of Science, Jazan University, Jazan, KSA \\ ${ }^{3}$ Faculty of Basic Studies, Future University, Khartoum, Sudan \\ Email: nisreenawad8@gmail.com
}

How to cite this paper: Elthair, N.A., Mustafa, E.M. and Elbadawi, A.A. (2020) The Electrical and Optical Properties of $\mathrm{Zn}_{0.5} \mathrm{Li}_{2 \mathrm{x}} \mathrm{Mg}_{0.5-\mathrm{x}} \mathrm{Fe}_{2} \mathrm{O}_{4}$ Lithium Doped Nanoparticle Prepared by Coprecipitation Method. Open Journal of Applied Sciences, 10, 551-560.

https://doi.org/10.4236/ojapps.2020.109039

Received: August 11, 2020

Accepted: September 13, 2020

Published: September 16, 2020

Copyright $\odot 2020$ by author(s) and Scientific Research Publishing Inc. This work is licensed under the Creative Commons Attribution International License (CC BY 4.0).

http://creativecommons.org/licenses/by/4.0/ (c) (i) Open Access

\begin{abstract}
In this study, nano ferrite materials were produced to replace costive industrial materials [1]. Ferrite nanoparticles are the interesting material due to their rich and unique physical and chemical properties. They find applications in catalysis, bio-processing, medicine, magnetic recording, adsorption, devices etc. Using co-participation method, five nano ferrite samples $\mathrm{Zn}_{0.5} \mathrm{Mg}_{0.5-\mathrm{x}} \mathrm{Li}_{2 \mathrm{x}} \mathrm{Fe}_{2} \mathrm{O}_{4}(\mathrm{x}=0.00,0.10,0.20,0.30$ and 0.40$)$ were prepared. The electrical and optical properties of the $\mathrm{Zn}_{0.5} \mathrm{Mg}_{0.5-\mathrm{x}} \mathrm{Li}_{2 \mathrm{x}} \mathrm{Fe}_{2} \mathrm{O}_{4}$ samples were studied using the Ultraviolet-visible (UV-Vis) spectroscopy. The results verified that the formation of the absorption coefficient of the five samples of $\mathrm{Zn}_{0.5} \mathrm{Mg}_{0.5-\mathrm{x}} \mathrm{Li}_{2 \mathrm{x}} \mathrm{Fe}_{2} \mathrm{O}_{4}$ increased with the increase of Lithium ( $\left.\mathrm{Li}_{2 \mathrm{x}}\right)$. The energy band gap of the $\mathrm{Zn}_{0.5} \mathrm{Mg}_{0.5-\mathrm{x}} \mathrm{Li}_{2 \mathrm{x}} \mathrm{Fe}_{2} \mathrm{O}_{4}$ samples ranged from 3.28 to $3.12 \mathrm{eV}$ [1]. The extinction coefficient $(\mathrm{K})$ for five samples of $\mathrm{Zn}_{0.5} \mathrm{Li}_{2 \mathrm{x}} \mathrm{Mg}_{0.5-\mathrm{x}} \mathrm{Fe}_{2} \mathrm{O}_{4}$ increased with the increase of Lithium $\left(\mathrm{Li}_{2 \mathrm{x}}\right)$ at $338 \mathrm{~nm}$ from 0.074 to 0.207 . The high magnitude of optical conductivity is $\left(1.34 \times 10^{12} \mathrm{sec}^{-1}\right)$ and the maximum value of electrical conductivity is $42(\Omega \cdot \mathrm{cm})^{-1}$. This may due to the electrical and optical properties of lithium.
\end{abstract}

\section{Keywords}

$\mathrm{Zn}_{0.5} \mathrm{Mg}_{0.5-\mathrm{x}} \mathrm{Li}_{2 \mathrm{x}} \mathrm{Fe}_{2} \mathrm{O}_{4}$, Nano Ferrites, UV.vis, Co-Precipitation, Electrical Properties, Optical Properties

\section{Introduction}

Particles in the size range of approximately 1 - $100 \mathrm{~nm}$ can display novel optical, 
electric, magnetic properties because of quantum confinement and surface effects that may find many important technological applications [2] [3] [4]. Nanotechnology is well-known as a very important key technology in science. In the field of material science, Ferrites are well-known magnetic nanomaterial's intensively studied as a recording media due to their superior physical properties [5] [6] [7]. These properties make ferrites an ideal candidate for technical applications such as magnetic resonance imaging enhancement, catalysis, sensors and pigments [8]. Spinel nano ferrites $\left(\mathrm{AB}_{2} \mathrm{O}_{4}\right)$ are materials of today's research due to their amazing structural, dielectric, electrical and magnetic properties [9]. Such properties are dependent on the nature of cations, their charges and their distribution among tetrahedral (A) and octahedral (B) sites [10]. Various physi$\mathrm{cal}$ and chemical methods of preparation have been developed to achieve nano-sized ferrite particles such as sol-gel [11], chemical co-precipitation [12], hydrothermal [13], and chemical combustion route [14]. Among them, the chemical co-precipitation method seems to be the most convenient method for the synthesis of $\mathrm{Zn}-\mathrm{Co}-\mathrm{Mg}$ ferrites. It is very simple and has better control over the crystalline size and other properties of the materials [15]. In this work, $\mathrm{Zn}_{0.5} \mathrm{Mg}_{0.5-\mathrm{x}} \mathrm{Li}_{2 \mathrm{x}} \mathrm{Fe}_{2} \mathrm{O}_{4}$ nano ferrite where ( $\mathrm{x}=0.1,0.2,0.3,0.4$ and 0.5 ) was synthesized using co-precipitation methods. Ultraviolet-visible spectrometer (UV) was used to study the optical, electric and magnetic properties of nanoparticles [16].

\section{Materials and Methods}

$\mathrm{Zn}_{0.5} \mathrm{Mg}_{0.5-\mathrm{x}} \mathrm{Li}_{2 \mathrm{x}} \mathrm{Fe}_{2} \mathrm{O}_{4}$ nanoparticles samples ( $\mathrm{x}=0.00,0.10,0.20,0.30$ and 0.40 ) were studied by the co-precipitation method [1]. The raw stoichiometric materials are $\mathrm{FeCl}_{3}, \mathrm{MgCl}_{2} \cdot 6 \mathrm{H}_{2} \mathrm{O}, \mathrm{LiCl} \cdot \mathrm{H}_{2} \mathrm{O}, \mathrm{ZnCl}_{2}$ with high pure, $\mathrm{NaOH}$ was used to found the required solutions with required molarities. Firstly, the solution of $\mathrm{MgCl}_{2} \cdot 6 \mathrm{H}_{2} \mathrm{O} 0.2 \mathrm{M}(25 \mathrm{ml}), \mathrm{ZnCl}_{2}$ and $\mathrm{FeCl}_{3} 0.4 \mathrm{M}(25 \mathrm{ml})$ were mixed, next, slowly added to $\mathrm{NaOH}$ solution with stirring to obtain a mixture of $\mathrm{pH} 11-12$. The colloid solution was kept in a water bath at $80^{\circ} \mathrm{C}$ for $1 \mathrm{hrs}$ to the removal of $\mathrm{NaCl}_{2}$ and $\mathrm{H}_{2} \mathrm{O}$ from the powder. The produced powder was washed by deionized water until the filtrate had a $\mathrm{pH}$ 7. Then the samples were dried and grinned to absolute powder and annealed to $450^{\circ} \mathrm{C}$ for $6 \mathrm{hrs}$ in temperature-controlled muffle furnace Vulcan A-550 at a heating rate $10^{\circ} \mathrm{C} / \mathrm{min}$. The absorption of a solution with different concentrations was calculated using UV min 1240 spectrometer Shimadzu.

\section{Results and Discussion}

UV-VIS absorbance behaviour of curves was found to be the same for five samples of $\mathrm{Zn}_{0.5} \mathrm{Li}_{2 \mathrm{x}} \mathrm{Mg}_{0.5-\mathrm{x}} \mathrm{Fe}_{2} \mathrm{O}_{4}$; as shown in Figure 1. The figure shows the relation between absorbance and wavelengths for five samples of $\mathrm{Zn}_{0.5} \mathrm{Li}_{2 \mathrm{x}} \mathrm{Mg}_{0.5-\mathrm{x}} \mathrm{Fe}_{2} \mathrm{O}_{4}$. It depicts the rapid increase of the absorption at wavelengths $340 \mathrm{~nm}$. It indicated an Lithium index $\left(\mathrm{Li}_{2 \mathrm{x}}\right)$ in the absorbance value, as the absorbance value increases with the increase of Lithium index $\left(\mathrm{Li}_{2 x}\right)$. 
Absorption coefficient ( $\alpha$ ): It describes how much light of a given color is absorbed by a material of a given thickness. The absorption coefficient $(\alpha)$ of the five prepared samples $\left(\mathrm{Zn}_{0.5} \mathrm{Li}_{2 \mathrm{x}} \mathrm{Mg}_{0.5-\mathrm{x}} \mathrm{Fe}_{2} \mathrm{O}_{4}\right)$ was found using the following relation:

$$
\alpha=\frac{2.303 \times A}{t}
$$

where $(A)$ is the absorbance and $(t)$ is the optical length in the samples. Figure 2 shows that the $\mathrm{Zn}_{0.5} \mathrm{Li}_{2 \mathrm{x}} \mathrm{Mg}_{0.5-\mathrm{x}} \mathrm{Fe}_{2} \mathrm{O}_{4}$ plot of $(\alpha)$ with wavelength $(\lambda)$ was the top among the five samples. The highest value of $(\alpha)$ for all samples was in the U.V region $(340 \mathrm{~nm})$. This means that the transition must be corresponding to a direct electronic transition, and the properties of this state are important since they are responsible for electrical conduction. Also, this figure shows that the value of $(\alpha)$ for the five samples increases with the increase of the Lithium index $\left(\mathrm{Li}_{2 \mathrm{x}}\right)$, which explains that lithium has a high absorbency [17] [18].

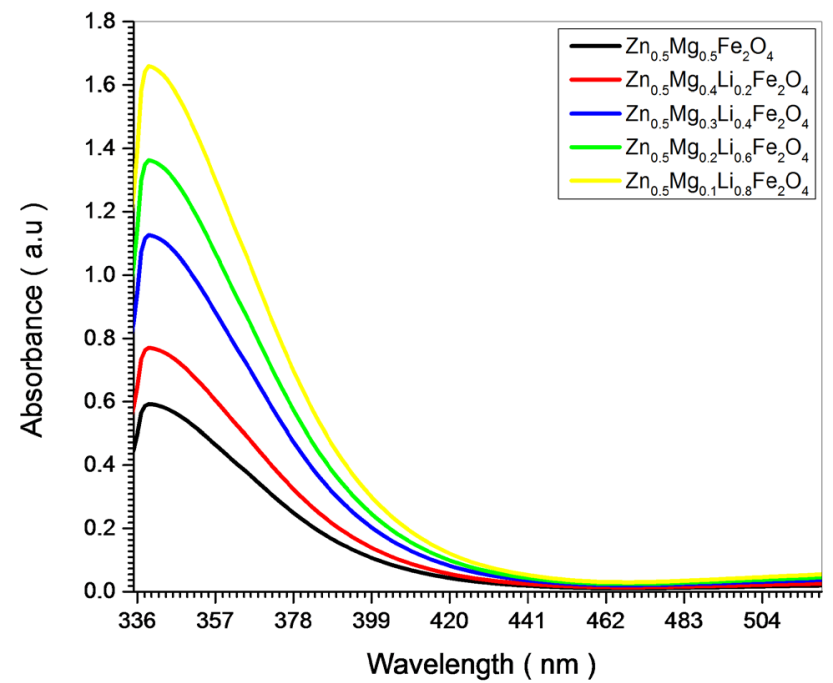

Figure 1. The relation between absorbance and wavelengths of $\mathrm{Zn}_{0.5} \mathrm{Li}_{2 \mathrm{x}} \mathrm{Mg}_{0.5-\mathrm{x}} \mathrm{Fe}_{2} \mathrm{O}_{4}$ samples.

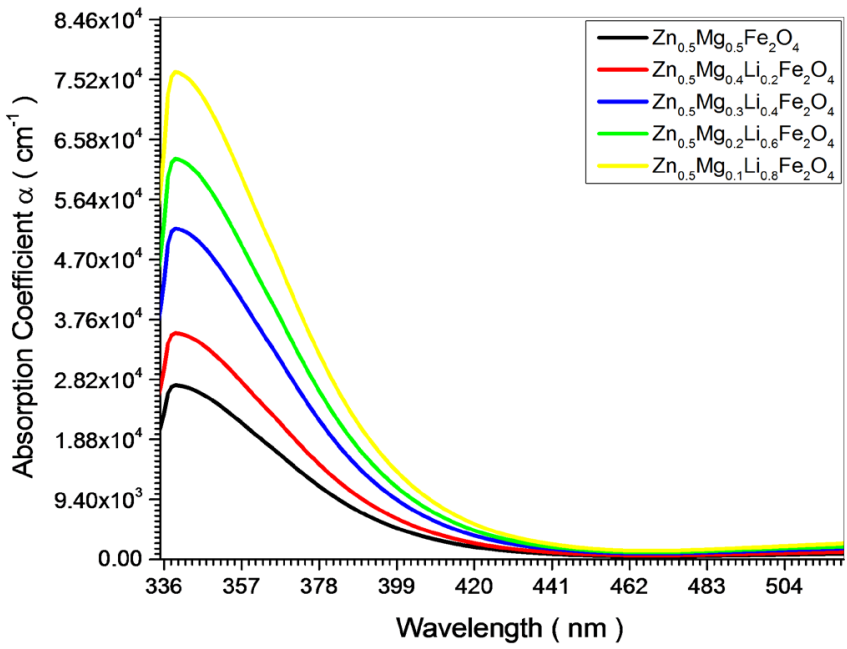

Figure 2. The relationship between absorption coefficient $(\alpha)$ and wavelengths of $\mathrm{ZnLi}_{2 \mathrm{x}} \mathrm{Mg}_{0.5} \mathrm{xFe}_{2} \mathrm{O}_{4}$ samples. 
Extinction coefficient $(K)$ : It is a measure of light lost due to scattering and absorption per unit volume. Extinction coefficient $(K)$ was calculated using the relation The variation at the $(\mathrm{K})$ values as a function of $(\lambda)$ for five samples of $\left(\mathrm{Zn}_{0.5} \mathrm{Li}_{2 \mathrm{x}} \mathrm{Mg}_{0.5-\mathrm{x}} \mathrm{Fe}_{2} \mathrm{O}_{4}\right)$ is shown in Figure 3, where it is observed that the spectrum shape of $(\mathrm{K})$ as the same shape of $(\alpha)$. The Extinction coefficient $(\mathrm{K})$ for five samples of $\mathrm{Zn}_{0.5} \mathrm{Li}_{2 \mathrm{x}} \mathrm{Mg}_{0.5-\mathrm{x}} \mathrm{Fe}_{2} \mathrm{O}_{4}$ in Figure 3 indicated that the value of $(\mathrm{K})$ at the wavelength depends on the samples treatment method, where the value of $(\mathrm{K})$ at $338 \mathrm{~nm}$ for $\mathrm{Zn}_{0.5} \mathrm{Mg}_{0.5} \mathrm{Fe}_{2} \mathrm{O}_{4}$ sample equals 0.074 while it was 0.207 for the other sample $\left(\mathrm{Zn}_{0.5} \mathrm{Li}_{0.1} \mathrm{Mg}_{0.8} \mathrm{Fe}_{2} \mathrm{O}_{4}\right)$ at the same wavelength. The Extinction coefficient (k) increased with the increase of Lithium index $\left(\mathrm{Li}_{2 \mathrm{x}}\right)$ in the $\mathrm{Zn}_{0.5} \mathrm{Li}_{0.2 \mathrm{x}} \mathrm{Mg}_{0.5-\mathrm{x}} \mathrm{Fe}_{2} \mathrm{O}_{4}$ samples.

The optical energy gap $\left(E_{g}\right)$ : It is the threshold for photons to be absorbed. The optical energy gap $\left(\mathrm{E}_{\mathrm{g}}\right)$ has been calculated by the relation $(\alpha \mathrm{hv})^{2}=\mathrm{C}(\mathrm{hv}-$ $\mathrm{E}_{\mathrm{g}}$ ) where $(\mathrm{C})$ is constant. By plotting $(\alpha \mathrm{hv})^{2}$ vs photon energy (hv), as shown in Figure 4 for the five prepared samples and by extrapolating the straight thin portion of the curve to intercept the energy axis, the value of the energy gap has been calculated. In this figure, the value of $\left(\mathrm{E}_{\mathrm{g}}\right)$ for $\mathrm{Zn}_{0.5} \mathrm{Mg}_{0.5} \mathrm{Fe}_{2} \mathrm{O}_{4}$ sample was (3.282) eV while it was (3.121) eV for the $\mathrm{Zn}_{0.5} \mathrm{Li}_{0.8} \mathrm{Mg}_{0.1} \mathrm{Fe}_{2} \mathrm{O}_{4}$ sample. The decrease of $\left(\mathrm{E}_{\mathrm{g}}\right)$ seemed to be associated with the Lithium index $\left(\mathrm{Li}_{2 \mathrm{x}}\right)$ for $\left(\mathrm{Zn}_{0.5} \mathrm{Li}_{2 \mathrm{x}} \mathrm{Mg}_{0.5-\mathrm{x}} \mathrm{Fe}_{2} \mathrm{O}_{4}\right)$ samples as it was observed that the $\mathrm{E}_{\mathrm{g}}$ value has decreased with the increase of Lithium index $\left(\mathrm{Li}_{2 \mathrm{x}}\right)$ confirming that it is the reason for the bandgap shifts [1] [19] [20].

The refractive index ( $\boldsymbol{n})$ : It is a dimensionless number that describes how fast light travels through the material. The refractive index (n) is the ratio between the speed of light in a vacuum to its speed in a material which does not absorb this light. The value of $n$ was calculated using the equation Where $(R)$ is the reflectivity. The variation of $(n)$ vs $(\lambda)$ for the five samples is shown in Figure 5 . The figure depicts the relationship of the five prepared samples by $\mathrm{Zn}_{0.5} \mathrm{Li}_{2 \mathrm{x}} \mathrm{Mg}_{0.5-\mathrm{x}} \mathrm{Fe}_{2} \mathrm{O}_{4}$ refractive index $(n)$ spectra. The maximum value of $(n)$ is (2.159) for all samples

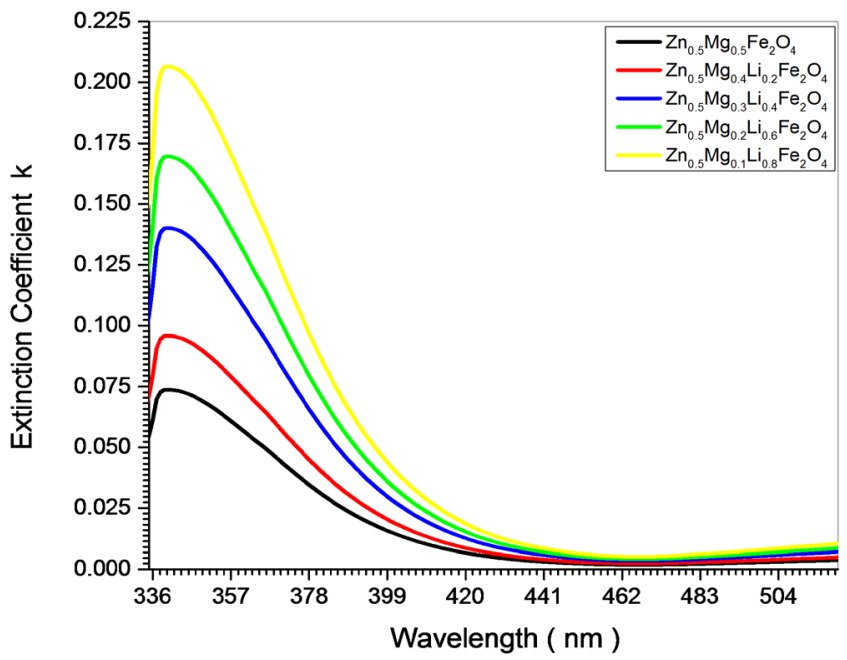

Figure 3. The relationship between extinction coefficient $(\mathrm{k})$ and wavelengths of $\mathrm{Zn}_{0.5} \mathrm{Li}_{2 \mathrm{x}} \mathrm{Mg}_{0.5} \mathrm{xFe}_{2} \mathrm{O}_{4}$ samples. 


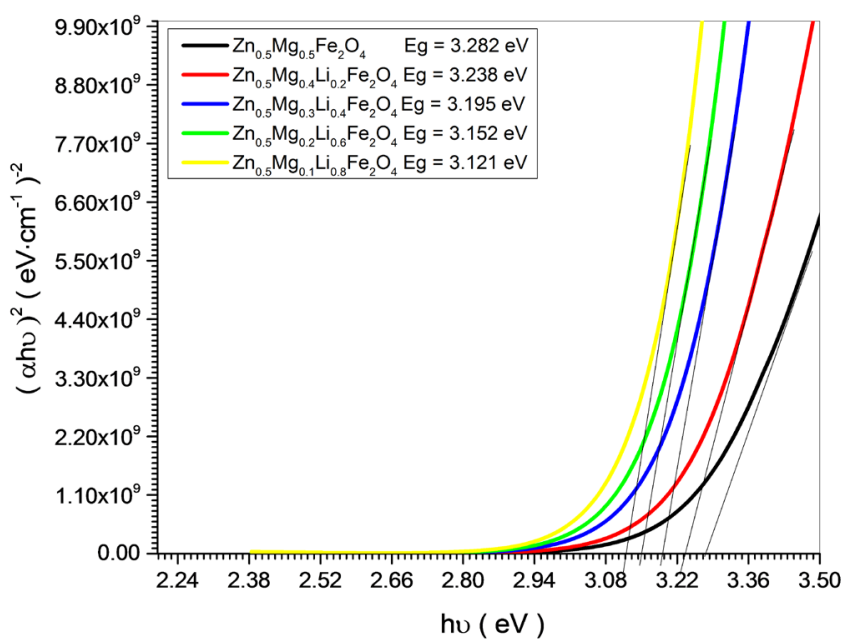

Figure 4. The optical energy bandgap of $\mathrm{Zn}_{0.5} \mathrm{Li}_{2 \mathrm{x}} \mathrm{Mg}_{0.5-\mathrm{x}} \mathrm{Fe}_{2} \mathrm{O}_{4}$ samples.

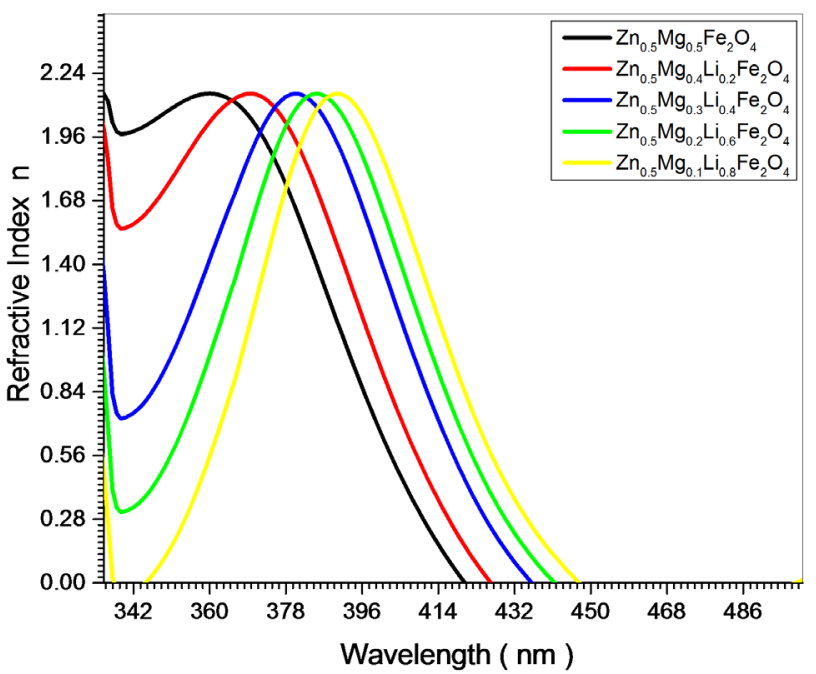

Figure 5. The relationship between refractive index and wavelengths of $\mathrm{Zn}_{0.5} \mathrm{Li}_{2 \mathrm{x}} \mathrm{Mg}_{0.5-\mathrm{x}} \mathrm{Fe}_{2} \mathrm{O}_{4}$ samples.

at the different wavelength which is agreement with (redshift when the Lithium index $\left(\mathrm{Li}_{2 \mathrm{x}}\right)$ increased for all samples of $\left(\mathrm{Zn}_{0.5} \mathrm{Li}_{2 \mathrm{x}} \mathrm{Mg}_{0.5-\mathrm{x}} \mathrm{Fe}_{2} \mathrm{O}_{4}\right)$.

Real dielectric constant $\left(\varepsilon_{1}\right)$ : Figure 6 shows the variation of the real dielectric constant $\left(\varepsilon_{1}\right)$ with the wavelength of five samples prepared by $\mathrm{Zn}_{0.5} \mathrm{Li}_{2 \mathrm{x}} \mathrm{Mg}_{0.5-\mathrm{x}} \mathrm{Fe}_{2} \mathrm{O}_{4}$ form, which was calculated using the equation $\varepsilon_{1}=\mathrm{n}^{2}-\mathrm{k}^{2}$; where the real the dielectric $\left(\varepsilon_{1}\right)$ is the normal dielectric constant. From Figure 6; the Real Dielectric Constant $\left(\varepsilon_{1}\right)$ increased in the region (340 to 432) $\mathrm{nm}$ for all samples of $\left(\mathrm{Zn}_{0.5} \mathrm{Li}_{2 \mathrm{x}} \mathrm{Mg}_{0.5-\mathrm{x}} \mathrm{Fe}_{2} \mathrm{O}_{4}\right)$, where the absorption of the samples at these wavelengths is small, but the polarization was high. The $\left(\varepsilon_{1}\right)$ reported a maximum value of (4.63) at a wavelength near $360 \mathrm{~nm}$ and $390 \mathrm{~nm}$ wavelength for the samples $\left(\mathrm{Zn}_{0.5} \mathrm{Mg}_{0.5} \mathrm{Fe}_{2} \mathrm{O}_{4}\right)$ and $\left(\mathrm{Zn}_{0.5} \mathrm{Li}_{0.8} \mathrm{Mg}_{0.1} \mathrm{Fe}_{2} \mathrm{O}_{4}\right)$, respectively. The effect of treatment by $\mathrm{Zn}_{0.5} \mathrm{Li}_{2 \mathrm{x}} \mathrm{Mg}_{0.5-\mathrm{x}} \mathrm{Fe}_{2} \mathrm{O}_{4}$ on the $\left(\varepsilon_{1}\right)$ was redshift when the Lithium index $\left(\mathrm{Li}_{2 \mathrm{x}}\right)$ increased for all samples of $\left(\mathrm{Zn}_{0.5} \mathrm{Li}_{2 \mathrm{x}} \mathrm{Mg}_{0.5-\mathrm{x}} \mathrm{Fe}_{2} \mathrm{O}_{4}\right)$. 


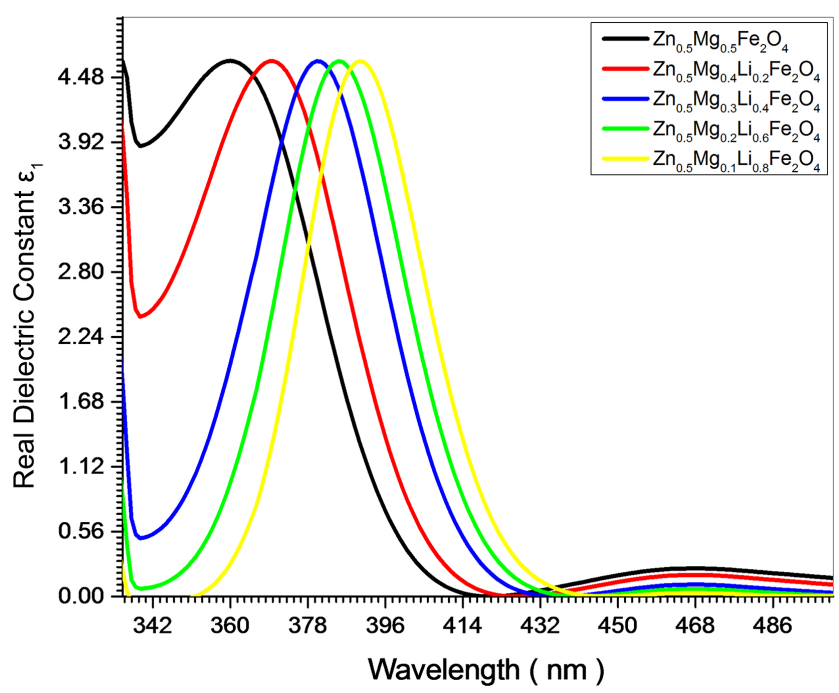

Figure 6. The relationship between real dielectric constant and wavelengths of $\mathrm{Zn}_{0.5} \mathrm{Li}_{2 \mathrm{x}} \mathrm{Mg}_{0.5-\mathrm{x}} \mathrm{Fe}_{2} \mathrm{O}_{4}$ samples.

The imaginary dielectric constant $\left(\varepsilon_{2}\right)$ : The imaginary dielectric constant $\left(\varepsilon_{2}\right)$ vs $(\lambda)$ was shown in Figure 7 . This value was calculated using the equation $\varepsilon_{2}$ $=2 \mathrm{nK}$, where $\left(\varepsilon_{2}\right)$ represents the absorption associated with free carriers. As shown in Figure 7; the shape of $\left(\varepsilon_{2}\right)$ is as the same as $\left(\varepsilon_{1}\right)$. This means that the refractive index was dominated in this behaviour. The maximum values of $\left(\varepsilon_{2}\right)$ are different according to the treatment operation, so, while the maximum value of $\left(\varepsilon_{1}\right)$ was (4.63) for $\left(\mathrm{Zn}_{0.5} \mathrm{Mg}_{0.5} \mathrm{Fe}_{2} \mathrm{O}_{4}\right)$ sample at wavelength near $360 \mathrm{~nm}$, the value of $\left(\varepsilon_{2}\right)$ for this sample was $(0.29)$ at the same wavelength. Similarly, the maximum value of $\left(\varepsilon_{1}\right)$ was (4.63) for the $\left(\mathrm{Zn}_{0.5} \mathrm{Li}_{0.8} \mathrm{Mg}_{0.1} \mathrm{Fe}_{2} \mathrm{O}_{4}\right)$ sample at wavelength $390 \mathrm{~nm}$, the value of $\left(\varepsilon_{2}\right)$ was $(0.34)$ at the same wavelength. This behaviour may be related to the different absorption mechanisms for the free carriers.

Electrical and optical conductivity: The optical conductivity is a measure of the frequency response of material when irradiated with light which is determined using the following relation,

$$
\delta_{\text {opt }}=\frac{\alpha \mathrm{nc}}{4 \pi}
$$

where (c) is the light velocity. The electrical conductivity can be estimated using the equation

$$
\delta_{\text {ele }}=\frac{2 \lambda \delta_{\text {opt }}}{\alpha}
$$

The high magnitude of optical conductivity $\left(1.34 \times 10^{12} \mathrm{sec}^{-1}\right)$ following relation confirms the presence of very high photo-response of the five samples prepared by $\mathrm{Zn}_{0.5} \mathrm{Li}_{2 \mathrm{x}} \mathrm{Mg}_{0.5-\mathrm{x}} \mathrm{Fe}_{2} \mathrm{O}_{4}$ form. The increased optical conductivity at high photon energies is due to the high absorbance of the five samples prepared by $\mathrm{Zn}_{0.5} \mathrm{Li}_{2 \mathrm{x}} \mathrm{Mg}_{0.5-\mathrm{x}} \mathrm{Fe}_{2} \mathrm{O}_{4}$ form and may be due to electron excitation by photon energy as it is shown in Figure 8 and Figure 9. The maximum value of electrical conductivity is $42(\Omega \cdot \mathrm{cm})^{-1}$ [21] [22] [23] [24] [25]. 


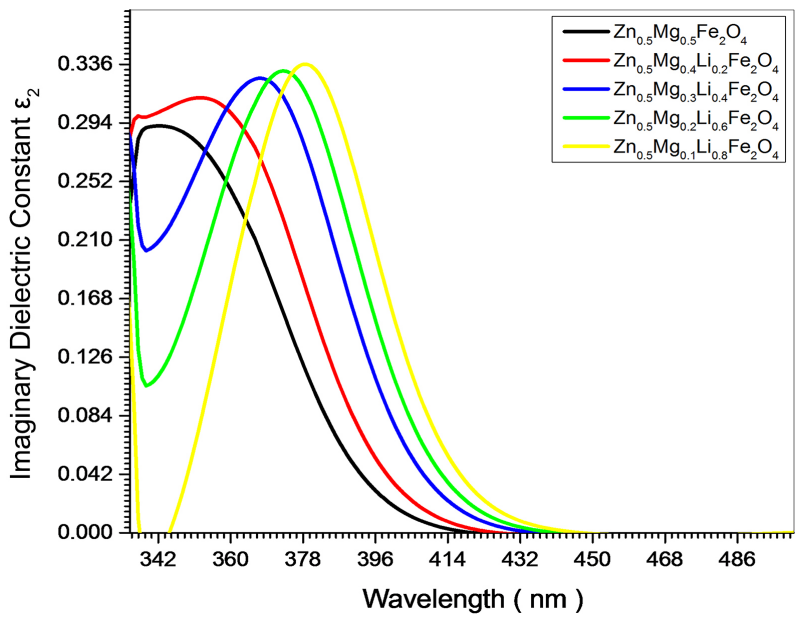

Figure 7. The relationship between imaginary dielectric constant and wavelengths of $\mathrm{Zn}_{0.5} \mathrm{Li}_{2 \mathrm{x}} \mathrm{Mg}_{0.5-\mathrm{x}} \mathrm{Fe}_{2} \mathrm{O}_{4}$ samples.

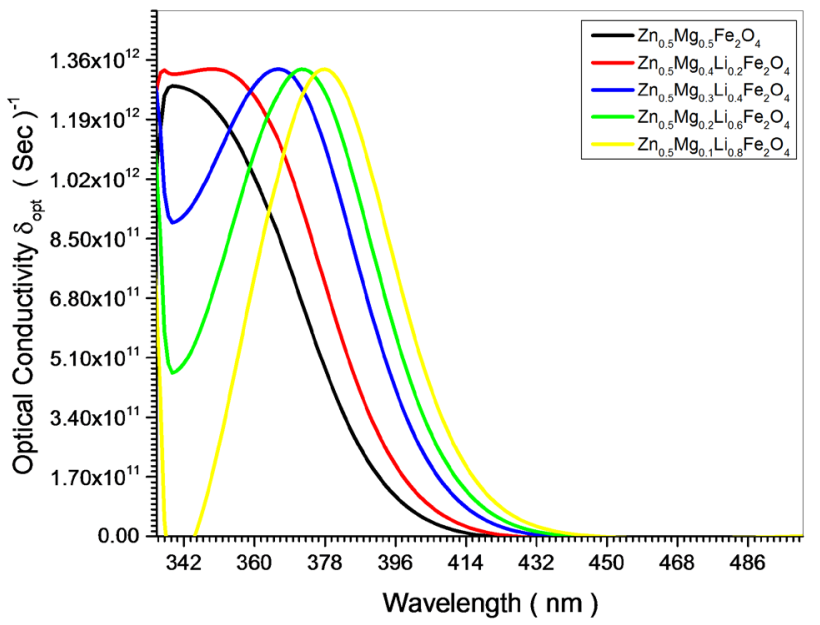

Figure 8. The relationship between optical conductivity and wavelengths of $\mathrm{Zn}_{0.5} \mathrm{Li}_{2 \mathrm{x}} \mathrm{Mg}_{0.5-\mathrm{x}} \mathrm{Fe}_{2} \mathrm{O}_{4}$ sample.

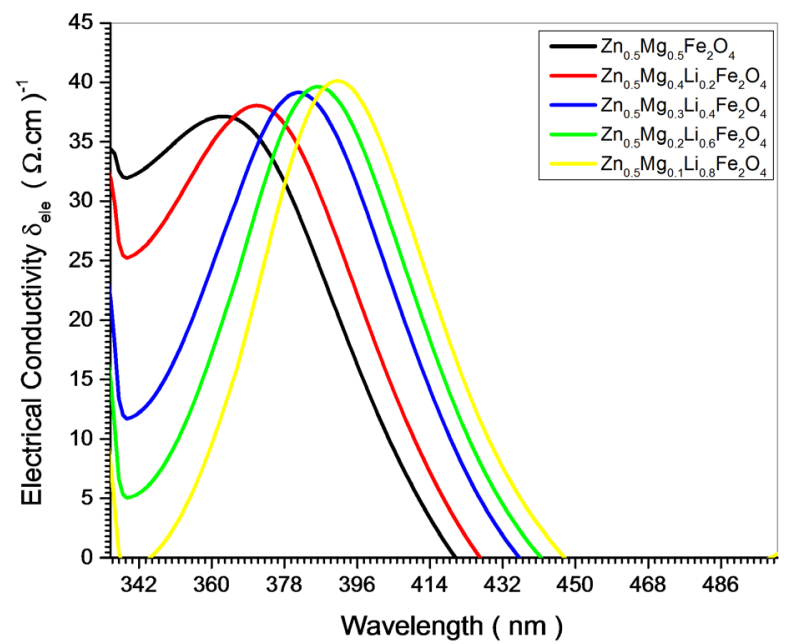

Figure 9. The relationship between electrical conductivity and wavelengths of $\mathrm{Zn}_{0.5} \mathrm{Li}_{2 \mathrm{x}} \mathrm{Mg}_{0.5-\mathrm{x}} \mathrm{Fe}_{2} \mathrm{O}_{4}$ samples. 


\section{Conclusion}

Nanocrystalline, $\mathrm{Zn}_{0.5} \mathrm{Mg}_{0.5-\mathrm{x}} \mathrm{Li}_{2 \mathrm{x}} \mathrm{Fe}_{2} \mathrm{O}_{4}$ nano ferrites $(\mathrm{x}=0.00,0.10,0.20,0.30$ and $0.40)$ samples are successfully prepared by co-precipitation approach. UV-visible spectroscopy showed that the bandgap energy of the samples was computed to be $3.28,3.24,3.19,3.15$ and $3.12 \mathrm{eV}$, for $\mathrm{Li}^{1+}$ concentration increased for the samples, respectively and the physical properties are increased with the lithium concentration and correspond to the Mirghni et al. study. This study was limited to the preparation and study of the composition and photometric properties. It is also recommended to study the rest of the physical and chemical properties to classify these materials and determine their applications.

\section{Conflicts of Interest}

The authors declare no conflicts of interest regarding the publication of this paper.

\section{References}

[1] Elthair, N.A., et al. (2019) The Effect of $\mathrm{Mg}^{2+}$ Substitution with $\mathrm{Li}^{1+}$ on Structural and Optical Properties of $\mathrm{Zn}_{0.5} \mathrm{Mg}_{0.5-\mathrm{x}} \mathrm{Li}_{2 \mathrm{x}} \mathrm{Fe}_{2} \mathrm{O}_{4}$ Nanoparticles. Open Journal of Applied Sciences, 9, 702-709. https://doi.org/10.4236/ojapps.2019.99057

[2] Mirghni, A.A., et al. (2015) Synthesis of $\mathrm{Zn}_{0.5} \mathrm{Co}_{\mathrm{x}} \mathrm{Mg}_{0.5-\mathrm{x}} \mathrm{Fe}_{2} \mathrm{O}_{4}$ Nano-Ferrites Using Co-Precipitation Method and Its Structural and Optical Properties. American Journal of Nano Research and Applications, 3, 27-32.

[3] Flores-Acosta, M., et al. (2003) Excitonic Absorption of Spherical PbS Nanoparticles in Zeolite A. Solid State Communications, 128, 407-411. https://doi.org/10.1016/j.ssc.2003.09.008

[4] Bognolo, G. (2003) The Use of Surface-Active Agents in the Preparation and Assembly of Quantum-Sized Nanoparticles. Advances in Colloid and Interface Science, 106, 169-181. https://doi.org/10.1016/j.cis.2003.07.002

[5] Pardavi-Horvath, M. (2000) Microwave Applications of Soft Ferrites. Journal of Magnetism and Magnetic Materials, 215, 171-183. https://doi.org/10.1016/S0304-8853(00)00106-2

[6] Spaldin, N.A. (2010) Magnetic Materials: Fundamentals and Applications. Cambridge University Press, Cambridge. https://doi.org/10.1017/CBO9780511781599

[7] Deraz, N. and Abd-Elkader, O.H. (2015) Structural, Morphological and Magnetic Properties of $\mathrm{Zn}_{0.5} \mathrm{Mg}_{0.5} \mathrm{Fe}_{2} \mathrm{O}_{4}$ as Anticorrosion Pigment. International Journal of Electrochemical Science, 10, 7138-7146.

[8] Kumar, S., Munjal, S. and Khare, N. (2017) Metal-Semiconductor Transition and Seebeck Inversion in $\mathrm{CoFe}_{2} \mathrm{O}_{4}$ Nanoparticles. Journal of Physics and Chemistry of Solids, 105, 86-89. https://doi.org/10.1016/j.jpcs.2017.02.003

[9] Kovalenko, A., et al. (2016) Towards Improved Efficiency of Bulk-Heterojunction Solar Cells Using Various Spinel Ferrite Magnetic Nanoparticles. Organic Electronics, 39, 118-126. https://doi.org/10.1016/j.orgel.2016.09.033

[10] Zhang, H., et al. (2017) Ultrasmall Ferrite Nanoparticles Synthesized via Dynamic Simultaneous Thermal Decomposition for High-Performance and Multifunctional T1 Magnetic Resonance Imaging Contrast Agent. ACS Nano, 11, 3614-3631. https://doi.org/10.1021/acsnano.6b07684 
[11] Ahmad, R., et al. (2016) Improved Electrical Properties of Cadmium Substituted Cobalt Ferrites Nano-Particles for Microwave Application. Journal of Magnetism and Magnetic Materials, 405, 28-35. https://doi.org/10.1016/j.jmmm.2015.12.019

[12] Hoque, S.M., et al. (2016) Synthesis and Characterization of $\mathrm{ZnFe}_{2} \mathrm{O}_{4}$ Nanoparticles and Its Biomedical Applications. Materials Letters, 162, 60-63.

https://doi.org/10.1016/j.matlet.2015.09.066

[13] Pulišova, P., et al. (2013) Structure and Magnetic Properties of Co and Ni Nano-Ferrites Prepared by a Two-Step Direct Microemulsions Synthesis. Journal of Magnetism and Magnetic Materials, 341, 93-99. https://doi.org/10.1016/j.jmmm.2013.04.003

[14] Ganjkhanlou, Y., et al. (2014) Application of Image Analysis in the Characterization of Electrospun Nanofibers. Iranian Journal of Chemistry and Chemical Engineering, 33, 37-45.

[15] Nikumbh, A., et al. (2014) Structural, Electrical, Magnetic and Dielectric Properties of Rare-Earth Substituted Cobalt Ferrites Nanoparticles Synthesized by the Co-Precipitation Method. Journal of Magnetism and Magnetic Materials, 355, 201-209. https://doi.org/10.1016/j.jmmm.2013.11.052

[16] Khorrami, S.A. and Manuchehri, Q.S. (2013) Magnetic Properties of Cobalt Ferrite Synthesized by Hydrothermal and Co-Precipitation Methods: A Comparative Study. Journal of Applied Chemical Research, 7, 15-23.

[17] Ali, B.M., et al. (2018) Effect of $\mathrm{Cu}^{2+}$ Doping on Structural and Optical Properties of Synthetic $\mathrm{Zn}_{0.5} \mathrm{Cu}_{\mathrm{x}} \mathrm{Mg}_{0.5-\mathrm{x}} \mathrm{Fe}_{2} \mathrm{O}_{4}(\mathrm{x}=0.0,0.1,0.2,0.3,0.4)$ Nano-Ferrites. Advances in Nanoparticles, 7, 1. https://doi.org/10.4236/anp.2018.71001

[18] Bushkova, V. (2015) Synthesis and Study of the Properties of Nanoferrites Obtained by the Sol-Gel Method with Participation of Auto-Combustion. Journal of Nano and Electronic Physics, 7, Article ID: 01023.

[19] Chattopadhyay, S., et al. (2019) Correlated Quartic Variation of Band Gap and NBE Energy in Sol-Gel Derived $\mathrm{Zn}_{1-\mathrm{x}} \mathrm{Co}_{\mathrm{x}} \mathrm{O}$ Nanoparticles. Materials Chemistry and Physics, 227, 236-241. https://doi.org/10.1016/j.matchemphys.2019.02.003

[20] Elthair, N.A., et al. (2019) Physical Properties Study of $\mathrm{Zn}_{0.5} \mathrm{Mn}_{0.5-\mathrm{x}} \mathrm{Li}_{2} \mathrm{xFe} \mathrm{O}_{2}$ Nanoparticle Series That Prepared by Co-Precipitation Method. Journal of Materials Science and Chemical Engineering, 7, 15-21. https://doi.org/10.4236/msce.2019.711002

[21] Zhang, Y., et al. (2010) Composition and Magnetic Properties of Cobalt Ferrite Nano-Particles Prepared by the Co-Precipitation Method. Journal of Magnetism and Magnetic Materials, 322, 3470-3475. https://doi.org/10.1016/j.jmmm.2010.06.047

[22] Kambale, R., et al. (2010) Structural and Magnetic Properties of $\mathrm{Co}_{1-\mathrm{x}} \mathrm{Mn}_{\mathrm{x}} \mathrm{Fe}_{2} \mathrm{O}_{4}(0 \leq$ $\mathrm{x} \leq 0.4)$ Spinel Ferrites Synthesized by Combustion Route. Journal of Alloys and Compounds, 490, 568-571. https://doi.org/10.1016/j.jallcom.2009.10.082

[23] Azhagushanmugam, S., Suriyanarayanan, N. and Jayaprakash, R. (2014) Magnetic Properties of Zinc-Substituted Cobalt Ferric Oxide Nanoparticles: Correlation with Annealing Temperature and Particle Size. Materials Science in Semiconductor Processing, 21, 33-37. https://doi.org/10.1016/j.mssp.2014.01.023

[24] de Mello, L.B., et al. (2019) Co-Precipitation Synthesis of (Zn-Mn)-Co-Doped Magnetite Nanoparticles and Their Application in Magnetic Hyperthermia. Journal of Alloys and Compounds, 779, 698-705.

https://doi.org/10.1016/j.jallcom.2018.11.280 
[25] Chand, J., et al. (2011) Structural, Electric and Dielectric Properties of $\mathrm{MgFe}_{2} \mathrm{O}_{4}$ Ferrite Processed by Solid-State Reaction Technique. International Journal of Theoretical and Applied Science, 3, 8-9. 